\title{
PENGARUH LATIHAN SQUAT JUMP TERHADAP HASIL UNDER THE BASKET SHOOT PADA PERMAINAN BOLA BASKET SISWA PUTRA EKTRAKULIKULER BASKET SMA NEGERI 01 TANJUNG BATU
}

\author{
Endie Riyoko ${ }^{1}$ \\ M. Al Ghani ${ }^{2}$ \\ Universitas PGRI Palembang \\ Universitas Islam Kalimantan Muhammad Arsyad Al Banjari Banjarmasin \\ Email: endieriyoko@univpgri-palembang.ac.id
}

\begin{abstract}
ABSTRAK
Permasalahan penelitian apakah ada pengaruh latihan Squat jump Terhadap Hasil Under The Basket Shoot Pada Permainan Bola Basket Siswa Putra Ektrakulikuler Basket SMA Negeri 01 Tanjung Batu. Penelitian menggunakan metode eksperimen terdiri dari kelas eksperimen dan kelas control. Sampel siswa putra Ektrakulikuler Basket berjumlah 60 orang. Data diambil melalui pretest dan posttest. Rata-rata pretest kelompok eksperimen 9,6 dan post test kelompok eksperimen 10,4. Sedengkan kelompok control rata-rata pretest 9,7 dan post test 9,8. Peningkatan rata-rata kelompok eksperimen lebih besar dibandingkan kelompok control setelah diberikan latihan squat jump selama 6 minggu dengan frekuensi latihan 3 kali dalam seminggu. Hasil penelitian menunjukan hasil nilai $t_{\text {hitung }}$ lebih besar dari $t_{\text {tabel. }}$. Hasil nya $t_{\text {hitung }}(3,94)>t_{\text {tabel }}(1,771)$ maka $\mathrm{H}_{\mathrm{a}}$ diterima dan $\mathrm{H}_{0}$ ditolak. Hasil penelitian memberikan pengaruh terhadap hasil Under The Basket Shoot.
\end{abstract}

Kata Kunci: Squat Jump; Hasil Under Shoot.

\begin{abstract}
Problems of Research Whether There is Influence of Exercises Squat jump Towards Results Under The Basketball Shoot Basketball Game At Student Basketball Ektrakulikuler Son SMA Negeri 01 Tanjung Batu. Research using experimental methods consist of classroom experiments and classroom control. A sample of students Basketball Ektrakulikuler son amounted to 60 people. The data is taken through a pretest and posttest. The average group pretest and post test experimental 9.6 experimental group 10.4. Sedengkan the average control group pretest 9.7 and post test 9.8. The average increase in the experimental group is larger than the control group after being given the squat jump exercise for 6 weeks with the frequency of exercise 3 times a week. The results of the research showed the result value of $t_{\text {hitung }}$ is greater than $t_{\text {tabel }}$ The results of his $t_{\text {hitung }}$ (3.94) > $t_{\text {tabel }}(1.771)$ then $H_{a}$ is accepted and rejected $H_{0}$. Results of the study give influence on the result Under The Basketball Shoot.
\end{abstract}

Keywords: Squat Jump; Results Under Shoot.

Dipublikasikan Oleh :

UPT Publikasi dan Pengelolaan Jurnal

Universitas Islam Kalimantan Muhammad Arsyad Al-Banjari Banjarmasin 


\section{PENDAHULUAN}

Olahraga merupakan suatu aktivitas untuk melatih tubuh tidak hanya jasmani tetapi juga rohani. Menurut Sukirno (2011 : 9), Olahraga sering berorientasi pada prestasi, membentuk seseorang mencapai kemampuan maksimal dalam kegiatan satu cabang olahraga. Jadi seorang invidu akan berpresstasi jika menekuni dengan baik salah satu jenis cabang olahraga yang ada. Dari sekian banyak cabang olahraga yang ada, cabang olahraga yang dipilih adalah permainan bola basket.

Teknik yang sangat penting dalam permainan bola basket adalah teknik tembakan yang baik dan harus dikuasai oleh setiap pemain untuk menghasilkan poin. Teknik tembakan dibagi menjadi dua yaitu tembakan dalam dan luar. Contoh tembakan luar adalah tembakan 3 poin. Namun tembakan ini lumayan sulit untuk anak SMA, berdasarkan statistik meski banyak pemain basket profesional yang terus mencoba tembakan tiga angka, namun pemain terbaik pun hanya berhasil 40-45 persen dari semua percobaan. Jadi berdasarkan hasil penelitian pun membuktikan tembakan luar kurang efektif dibandingkan dengan tembakan dalam.

Menurut Jon Oliver (2007 : 13), semakin dekat dengan ring basket, semakin besar kesempatanmu untuk melakukan tembakan dalam yang efektif untuk mendapatkan poin. Untuk itu teknik tembakan yang sesuai untuk anak SMA adalah tembakan dalam. Tembakan dalam yang terpenting dan sering digunakan dalam permainan bola basket adalah tembakan Under the basket shoot (tembakan bawah ring basket).

Under the basket shoot adalah tembakan yang sering digunakan ketika seorang pemain penyerang yang berada di dekat ring basket menerima sebuah umpan, merebut bola dari rebound, atau melakukan jump-stop setelah melakukan dribble-drive kearah ring basket. Untuk sebuah tembakan under the basket shoot di sebelah kanan atau kiri ring, posisikan bola kokoh di antara dua tangan. Melompatlah dengan kuat dengan kedua kaki sebagai tumpuan. Saat kamu melayang, julurkan kedua lenganmu ke arah ring dan papan sehingga bola dipegang pada posisi yang tinggi. Ketika kamu mencapai puncak lompatan, pindahkan bola dengan lembut kedua tangan ke telapak jari tangan yang akan di gunakan untuk menembak, gunakanlah lengan serta siku yang tidak melakukan tembakan untuk melindungi dari para pemain bertahan.

SMA Negeri 01 Tanjung Batu merupakan salah satu sekolah negeri berstandar nasional dengan akreditasi A yang berada di desa Tanjung Batu Kabupaten Ogan Ilir Ektrakulikuler bola basket banyak diminati oleh siswa hal ini di karenakan SMA Negeri 01 Tanjung Batu memiliki saranan dan prasarana yang baik, lapangan basket, ring dan bola namun ada permasalah dalam melakukan Under the basket shoot di SMA Negeri 01 Tanjung Batu sangat kurang baik mungkin dikarnakan belum diajarkanya latihan yang dapat menunjang kemampuan tembakan, kualitas lompatan yang kurang baik dan dapat berpengaruh pada power otot tungkai siswa.

Oleh sebab itu perlunya ada salah satu jenis latihan terhadap siswa ektrakulikuler basket yang nantinya dapat meningkatkan kualitas tembakan dalam ini (under the basket shoot). Umumnya di SMA untuk tembakan dalam yang khusus masih banyak mengalami kendala mulai dari bola yang tidak masuk ke ring basket yang disebabkan oleh kurang tinggi lompatan. Padahal untuk tembakan dalam dalam bola basket diperlukan power kaki yang kuat untuk melakukan lompatan yang tinggi. Salah satu bentuk latihan yang dapat digunakan yaitu squat jump.

Squat jump atau lompat jongkok merupakan latihan pliometrik untuk melatih tubuh bagian bawah. Latihan ini menargetkan otot paha depan, paha belakang, gluteus, dan betis. Squat jump adalah gerakan eksplosif. Cara latihannya, berjongkoklah hingga posisi squat, tekan ujung kaki dan dorong tubuh ke udara setingginya. Saat turun, segera tekuk lutut, turun kembali ke posisi squat dan melompat lagi. Posisi kaki harus dalam keadaan jinjit saat mendarat. Latihan ini berguna untuk meningkatkan eksplosif kaki. dari posisi jongkok, lompat ke atas. Berdasarkan latar belakang di atas maka permasalahan penelitian ini dapat dirumuskan sebagai berikut:

"Apakah latihan squat jump berpengaruh signifikan terhadap hasil under the basket shoot pada permainan bola basket siswa putra ekstrakulikuler basket SMA Negeri 01 Tanjung Batu".

\section{METODE}

Jenis Penelitian

Jenis penelitian ini adalah True Experimental Design yaitu jenis eksperimen yang dianggap betul dan baik karena dalam desain ini, penelitian dapat mengontrol semua variable luar yang mempengaruhi jalannya eksperimen. Menurut Sugiyono (2013 : 75), ciri utama dari True Experimental sampel yang digunakan untuk eksperimen maupun sebagai kelompok control diambil secara random dari populasi tertentu.

Sampel Penelitian

Penelitian ini menggunakan penelitian populasi dengan jumlah sampel kurang dari 100. Penulis mengambil kelas $\mathrm{X}$ dan XI sebagai populasi. Sampel yang digunakan adalah sebanyak 60 siswa sebagai orang coba, 30 orang sebagai kelompok eksperimen dan 30 orang sebagai kelompok kontrol.

Teknik Sampling

\section{Dipublikasikan Oleh :}


Dalam peneltian ini, teknik pengambilan sampling menggunakan teknik Random Sampling dengan menggunakan sistem Ordinal Pairing untuk menentukan kelompok eksperimen dan kelompok kontrol. Sampel melakukan pretest yaitu melakukan free throw.

Teknik Analisis Data

Analisis data dalam penelitian kuantitatif mengunakan statistik, yaitu mengunakan statistik deskriptif (Sugiyono, 2010 : 207). Analisis data yang peneliti gunakan adalah statistik deskriptif, uji normalitas, dan uji hipotesis.

Uji Normalitas Data

Uji normalitas data dilakukan untuk mengetahui normal tidaknya suatu data. Rumusan yang digunakan untuk menguji normalitas data adalah rumus koefisien pearson.

Ket : (Sudjana, 2005 : 109)

$\mathrm{Km}=$ Kemiringan

= Rata-rata

M0 = Modus

$\mathrm{S}=$ Simpangan

Data dikatakan normal jika nilai $\mathrm{K}$ terletak antara -1 sampai $+1(-1<\mathrm{K}<+1)$

Langkah-langkah untuk menguji normalitas tersebut antara lain :

a. Mencari rata-rata masing-masing kelompok, dengan rumus

(Sudjana, $2005: 70$ )

Ket :

= Rata-rata

$\mathrm{x}=$ Tanda interval kelas

$\mathrm{f}=$ Frekuensi sesuai interval kelas

b. Mencari modus, dengan rumus

(Sudjana, $2005: 77$ )

Ket :

M0 = Modus

$\mathrm{b}=$ Batas bawah kelas modal, yaitu interval dengan frequensi terbanyak

$\mathrm{p}=$ Panjang kelas

b1 = Frequensi kelas modus dikurangi frequensi kelas interval dengan kelas yang lebih kecil

b2 = Frequensi kelas modus dikurangi frequensi kelas interval dengan kelas yang lebih besar sesudah tanda kelas modus

c. Mencari Median, dengan rumus

(Sudjana, $2005: 79$ )

Ket :

$\mathrm{Me}=$ Median

b = batas bawah kelas median, kelas dimana median akan terletak

$\mathrm{p}=$ panjang kelas median

$\mathrm{n}$ = banyak data

$\mathrm{F}=$ jumlah semua frequensi dengan tanda kelas lebih dari tanda batas median

$\mathrm{F}=$ frequensi

d. Mencari simpangan baku/standar deviasi

(Sudjana, 2005 : 95)

Ket :

$\mathrm{S} 2$ = simpangan baku

$\mathrm{x} 1$ = tanda kelas

$\mathrm{f} 1$ = frequensi kelas

$\mathrm{n}=$ banyak data

Uji Homogenitas Data

Teknik untuk menguji homogenitas data, menggunakan uji bartlett dengan rumus

(Sudjana, $2005: 263$ )

Sampel akan homogen jika X2 hitung $\leq \mathrm{X} 2$ table, dan sampel tidak homogen jika X2 hitung $\geq$ dari X2 table 1. Cari satuan B dengan rumus

$\mathrm{B}=$

Dipublikasikan Oleh :

UPT Publikasi dan Pengelolaan Jurnal

Universitas Islam Kalimantan Muhammad Arsyad Al-Banjari Banjarmasin 
2. Cari varians dengan rumus

Uji Hipotesis

Uji hipotesis dilakukan untuk mengetahui apakah ada pengaruh latihan squat jump terhadap hasil under the basket shoot siswa putra kelas X SMA Negeri 01 Tanjung Batu.

Ho : Tidak ada pengaruh latihan squat jump terhadap hasil under the basket shoot pada siswa putra kelas $\mathrm{X}$ SMA Negeri 01 Tanjung Batu.

Ha : Ada pengaruh latihan squat jump terhadap hasil under the basket shoot pada siswa putra kelas X SMA Negeri 01 Tanjung Batu.

Bila data yang diperoleh berdistribusi normal dan homogen, maka digunakan statistik uji t, dengan rumus :

(Arikunto, 2010:354)

Ket :

$\mathrm{m}=$ Mean dari perbedaan pretest dan posttest perkelompok

$\mathrm{n}=$ banyak mean

$\mathrm{x}=$ deviasi setiap nilai $\mathrm{x} 2$ dan $\mathrm{x} 1$

$\mathrm{y}=$ deviasi setiap nilai $\mathrm{y} 2$ dan $\mathrm{y} 1$

$\mathrm{x}=$ kelompok eksperimen

$\mathrm{y}=$ kelompok control

dengan : didapat dari

didapat dari

Menggunakan taraf signifikansi (t table)

Ho di tolak jika t hitung $\geq$ dari t tabel

Ho diterima jika thitung < dari t table

Instrumen Penelitian

Instrument penelitian merupakan sebagai alat ukur dalam penelitian seperti variabel penelitian. Instrument penelitian ini, yaitu a) lapangan basket, b) bola basket, c) peluit, d) pemandu tes, e) pencatat hasil tes, f) blangko penilaian hasil under the basket shoot, g) alat tulis dan stopwatch.

\section{HASIL DAN PEMBAHASAN}

Pada penelitian latihan squat jump digunakan sebagai bentuk latihan untuk meningkatkan kemampuan tembakan under the basket shoot pada permainan bola basket. Dalam penelitian ini aspek yang dinilai adalah kemampuan siswa menembak bola basket. Untuk mengetahui sejauh mana pengaruh latihan squat jump terhadap tembakan under the basket shoot bola basket dihitung dengan membandingkan antara nilai pretest dan post test pada masing-masing kelompok. Hasil rata-rata pretest kelompok eksperimen adala 9,6 dan post test rata-rata untuk kelompok eksperimen adalah 10,4. Sedengkan untuk kelompok control nilai rata-rata untuk pretest adalah 9,7 dan post test 9,8. Peningkatan rata-rata untuk kelompok eksperimen lebih besar dibandingkan kelompok control setelah diberikan latihan squat jump selama 6 minggu dengan frekuensi latihan 3 kali dalam seminggu.

Pembahasan diatas berdasarkan temuan dilapangan, sedangkan berdasarkan data yang dikumpul diketahui bahwa data berdistribusi normal dan data berasal dari sampel yang homogen, kemudian dilakukan uji hipotesis dengan statistik uji t, dan didapatkan thitung $(3,94)>$ ttabel $(1,771)$ maka terdapat perbedaan yang signifikan antara kelompok eksperimen dan kontrol. Dengan demikian maka hipotesis H0 ditolak dan H1 diterima. Pernyataan H1 yaitu "Ada pengaruh latihan squat jump terhadap under the basket shoot permainan bola basket siswa putra ekstrakulikuler basket SMA Negeri 01 Tanjung Batu”. Dari hasil perhitungan dan analisis seluruh data yang ada, maka hasilnya memberikan jawaban terhadap permasalahan yang diajukan dalam penelitian ini. Berdasarkan hasil penelitian ini bahwa latihan squat jump memberikan pengaruh yang signifikan terhadap hasil under the basket shoot bola basket.

\section{PENUTUP}

\section{Kesimpulan}

Berdasarkan hasil penelitian dan hasil perhitungan statistik yang diperoleh dari penelitian ini, maka penulis menyimpulkan bahwa ada pengaruh latihan squat jump terhadap hasil under the basket shoot pada permainan bola basket siswa putra ektrakulikuler basket SMA Negeri 01 Tanjung Batu, hal ini dapat dilihat dari analisis data dengan menggunakan uji t diperoleh hasil yang menunjukkan thitung > ttabel, yaitu 3,94>1,77 maka Ha diterima dan Ho ditolak.

Dipublikasikan Oleh :

UPT Publikasi dan Pengelolaan Jurnal

Universitas Islam Kalimantan Muhammad Arsyad Al-Banjari Banjarmasin 
Saran

Berdasarkan hasil penelitian, maka penulis mengemukakan saran-saran sebagai berikut:

1.Bagi para siswa, metode latihan squat jump dapat digunakan sebagai latihan untuk meningkatkan hasil under the basket shoot dalam permainan bola basket.

2.Bagi para guru dan pelatih, penelitian ini dapat dijadikan sebagai acuan sebagai jawaban tentang pengaruh latihan squat jump dapat digunakan sebagai latihan untuk meningkatkan hasil under the basket shoot dalam permainan bola basket.

3.Bagi sekolah, agar dapat menerapkan latihan squat jump sebagai pedoman latihan yang dapat meningkatkan kemampuan tembakan under the basket shoot dalam permainan bola basket

4.Rekomendasikan penelitian lebih lanjut untuk meneliti berbagai bentuk latihan yang mendukung terhadap squat jump pada permainan bola basket, karena dapat memberikan manfaat yang besar bagi pengembangan variasi latihan untuk kemajuan prestasi cabang olahraga.

\section{REFERENSI}

Ahmadi, Nuril.2010. Permainan Bola Basket.Solo: Era Intermedia

Ahmad, Maskur. 2006. Pengetahuan Dasar Ilmu Kesehatan Olahraga. Palembang: Universitas Sriwijaya Ahmad, Maskur. 2007. Kinesiologi Olahraga. Palembang: Universitas Sriwijaya

Arikunto, Suharsimi. 2006. Prosedur Penelitian Suatu Pendekatan Praktik. Jakarta: Rineka Cipta

Ismaryati. 2011. Tes dan Pengukuran Olahraga. Surakarta: UNS Press

Oliver, Jon.2003. Dasar-dasar Bola Basket: United Graphics

Perbasi.2010. Official Basketball Rules.Jakarta : Perbasi

Purwanto. 2013. Evaluasi Hasil Belajar. Yogyakarta: Pustaka Belajar

Sudjana. 2005. Metoda Statistika. Bandung: Tarsito

Sugiyono. 2013. Metode Penelitian Kuantitatif Kualitatif dan R\&D. Bandung: Alfabeta

Sukadiyanto. 2005. Pengantar Teori dan Metodologi Melatih Fisik. Yogyakarta: Fakultas Ilmu Keolahragaan. Universitas Negeri Yogyakarta

Sukirno. 2011. Kesehatan Olahraga Dan Program Latihan Kesegaran Jasmani.Palembang: Universitas Sriwijaya Widiastuti. (2011). Tes dan Pengukuran Olahraga. Jakarta : PT Bumi Timur Jaya 